\title{
COMPARISON BETWEEN MULTICOPTER UAV AND TOTAL STATION FOR ESTIMATING STOCKPILE VOLUMES
}

\author{
C. Arango ${ }^{a}$, C. A. Morales ${ }^{a}$ \\ ${ }^{a}$ Universidad de los Andes, Departamento de Ingeniería Civil y Ambiental, , Carrera 1 Este No.19 A - 40, Office: ML640, Bogotá, \\ Colombia - (c.arango954, andr-mor)@uniandes.edu.co
}

KEY W ORDS: total station, multicopter uav, data acquisition, comparison, stockpile, volumes

\begin{abstract}
:
Currently the UAV (Unmanned Aerial Vehicle) have become an alternative for different engineering applications, especially in surveying, one of these applications is the calculation of volumes of stockpiled material, but there are questions about its accuracy and efficiency, the purpose of this article is to compare traditional surveying methods for estimating total volumes through data obtained by total stations and data obtained by a multicopter UAV. In order to answer these questions we obtain data from the same location and the results were compared.
\end{abstract}

After comparing the results it was found that there was a 2,88\% difference between the volume calculated with the total station data and the actual volume, and $-0,67 \%$ difference between the volume calculated with the UAV data and the actual volume, concluding that the estimated volume with UAV data is more accurate.

\section{INTRODUCTION}

Currently the UAV systems have become an alternative for different engineering applications (Siebert and Teizer, 2014), one of these applications is the estimation of volumes of stockpiled material with the use of photogrammetry and DTM generation,

There are several methods for estimate the stockpile volumes. In the traditional method the data is obtained from a total station, in this method you need to hold a prism pole and occupy areas of a large pile of material, this method can be time consuming and dangerous in some cases.

There are other methods for obtain data to estimate the stockpile volumes with different technologies like Lidar (aerial or terrestrial), GNSS, and UAV. The goal of this article is to evaluate the UAV multicopter technology in comparison with the traditional method and obtain the difference between the both methods.

\subsection{Multicopter}

There are many UAV systems today in the market for commercial applications, one of these are the multicopter or multirotor UAV, this kind of UAV have some advantage and limitations in comparison to other UAV systems, their main advantage is the easy of operation, high flexibility, and stability. Most recent models offer a payload of up to $5 \mathrm{~kg}$ and can carry complex and heavy surveying systems, such as a single-lens reflex (SLR) cameras. Commonly used multicopters have at least four rotors (quadrocopter), but can have more (hexacopter or octocopter) for redundancy purposes. (Siebert and Teizer, 2014)

\subsection{Total Station}

A total station or TST (total station theodolite) is an electronic/optical instrument used for surveying. The total station is an electronic theodolite (transit) integrated with an EDM (electronic distance meter) to read slope distances from the instrument to a particular point. (Kavanagh and Glenn Bird, 1996)

\subsection{UAV Photogrammetry}

The use of UAV for geomatics offers a real time application and low-cost alternatives to the classical manned aerial photogrammetry (Eisenbeiß, 2009). The expected ground pixel in a multicopter UAV flying at low altitude $(20-30$ meters $)$ can be less than $5 \times 5 \mathrm{~cm}$, and only small investments of time and money are required for small studies (Ouédraogo et al, 2014).

With these aerial images we can generate 3D models (Eisenbeiß, 2009, Remondino et al, 2011, Zongjian, 2008 ) or DSM, the use of stereoscopic aerial photographic pairs for generating DSMs has been extensively investigated see Gruen (2012) for a review of the development of image-matching since 1960 (Ouédraogo et al, 2014).

However the accuracy of the use of UAV for estimate stockpile volumes needs to be investigated further.

\section{METHODOLOGY}

\subsection{Data Acquisition}

For this investigation we use two methodologies for data acquisition, the first one with a total station, and the second with a multicopter UAV.

\footnotetext{
* Corresponding author
} 
2.1.1 Total Station: For the data acquisition with the total station, we set up a Leica TS-02 total station, with the specifications shown in the Table 1, in different geo-referenced points (with GNSS) around the stockpile, later, we walk over the stockpile with a prism and a pole surveying characteristics breaklines, in that way we collect all the necessary points to estimate the volume by any methodology.

\begin{tabular}{|l|l|}
\hline Description & TS02plus \\
\hline $\begin{array}{l}\text { 1" angular accuracy } \\
\text { Enhanced measurement accuracy to } \\
\text { prism }\end{array}$ & - \\
$\begin{array}{l}\text { Reflectorless measurement range } \\
\text { Display with graphics and display } \\
\text { illumination }\end{array}$ & $\begin{array}{l}500 \mathrm{~m} \text { option } \\
\text { Black \& White high } \\
\text { resolution }\end{array}$ \\
\hline
\end{tabular}
Table 1. Leica Ts-02 Specifications

Source: http://www.leica-geosystems.com/en/Leica-FlexLineTS02plus_99086.htm

2.1.2 Multicopter: for the data acquisition with the multicopter we use a DJI Phantom 2 vision plus, the specifications of this multicopter are shown in Table 2, for the study area, two flights of 14 minutes were made, The configuration of the two flights was the same as shown in Table 3 , in this method we use the geo-referenced points (with GNSS) around the stockpile as ground control points (GCP), in order to calibrate the image before.

\begin{tabular}{|c|c|c|}
\hline Aircraft & $\begin{array}{l}\text { Supported Battery } \\
\text { Weight (Battery \& } \\
\text { Propellers Included) } \\
\text { Hover Accuracy } \\
\text { Max Yaw Angular } \\
\text { Velocity } \\
\text { Max Tiltable Angle } \\
\text { Max Ascent / Descent } \\
\text { Speed } \\
\text { Max Flight Speed } \\
\text { Diagonal Motor-Motor } \\
\text { Distance }\end{array}$ & $\begin{array}{l}\text { DJI 5200mAh LiPo } \\
\text { Battery } \\
1242 \mathrm{~g} \\
\text { Vertical: } 0.8 \mathrm{~m} ; \\
\text { Horizontal: } 2.5 \mathrm{~m} \\
200^{\circ} / \mathrm{s} \\
35^{\circ} \\
\text { Ascent: } 6 \mathrm{~m} / \mathrm{s} ; \text { Descent: } \\
2 \mathrm{~m} / \mathrm{s} \\
15 \mathrm{~m} / \mathrm{s} \text { (Not } \\
\text { Recommended) } \\
350 \mathrm{~mm}\end{array}$ \\
\hline Gimbal & $\begin{array}{l}\text { Working Current } \\
\text { Control Accuracy } \\
\text { Controllable Range } \\
\text { Maximum Angular } \\
\text { Speed }\end{array}$ & $\begin{array}{l}\text { Static : } 750 \mathrm{~mA} \text {; Dynamic } \\
: 900 \mathrm{~mA} \\
\pm 0.03^{\circ} \\
\text { Pitch : }-90^{\circ}-0^{\circ} \\
\text { Pitch : } 90^{\circ} / \mathrm{s}\end{array}$ \\
\hline Camera & $\begin{array}{l}\text { Operating Environment } \\
\text { Temperature } \\
\text { Sensor Size } \\
\text { Effective Pixels } \\
\text { Resolution } \\
\text { HD Recording } \\
\text { Recording FOV }\end{array}$ & $\begin{array}{l}0^{\circ} \mathrm{C}-40^{\circ} \mathrm{C} \\
1 / 2,3^{\prime \prime} \\
14 \text { Megapixels } \\
4384 \times 3288 \\
1080 \mathrm{p} 30 \& 720 \mathrm{p} \\
110^{\circ} / 85^{\circ}\end{array}$ \\
\hline $\begin{array}{l}\text { Remote } \\
\text { Control }\end{array}$ & $\begin{array}{l}\text { Operating Frequency } \\
\text { Communication } \\
\text { Distance (Open Area) }\end{array}$ & $\begin{array}{l}5.728 \mathrm{GHz}-5.85 \mathrm{GHz} \\
\text { CE Compliance: } 400 \mathrm{~m} \text {; } \\
\text { FCC Compliance: } 800 \mathrm{~m}\end{array}$ \\
\hline
\end{tabular}

\begin{tabular}{|l|l|l|}
\hline \multirow{1}{*}{$\begin{array}{l}\text { Receiver Sensitivity } \\
\text { (1\%PER) }\end{array}$} & $-93 \mathrm{dBm}$ \\
Transmitter Power & CE Compliance: 25mW; \\
& FCC Compliance: \\
& Working Voltage & $100 \mathrm{~mW}$ \\
& Built-In LiPo Battery & $3.7 \mathrm{~V}, 2000 \mathrm{mAh}$ \\
& Working & \\
Current/Capacity & Operating Frequency \\
Extender & Communication & $500-700 \mathrm{~m}$ \\
& Distance (Open Area) & \\
& Transmitter Power & $20 \mathrm{dBm}$ \\
& Power Consumption & $2 \mathrm{~W}$ \\
\hline
\end{tabular}

Table 2. DJI Phantom 2 vision plus specifications Source: http://www.dji.com/product/phantom-2-visionplus/spec

\begin{tabular}{|l|l|}
\hline Flight duration (average of the two flights) & $14 \mathrm{~min}$ \\
Altitude above ground & $50 \mathrm{~m}$ \\
Speed of flight & $2 \mathrm{~m} / \mathrm{s}$ \\
\hline
\end{tabular}

Table 3. Flight configuration

\subsection{Volume Estimation}

In order to estimate the volumes two methodologies were performed, one for the data obtained with the total station, and one methodology with data obtained by the multicopter.

2.2.1 Volume Estimation with Total Station Data: For estimate the volume of stockpile many methods can be used. i.e. trapezoidal method for rectangular or triangular prism, classical cross-sectioning for trapezoidal, Simpson's and improve methods using Simpson-based, cubic spline and cubic Hermite formula used for conventional method calculation (Yakar and Yilmaz, 2008, Hamzah and Said, 2011).

However, we use a software methodology to calculate the volume of the stock pile, with the data obtained by the TST.

After obtaining the field data with the TST, the data was downloaded to the computer with the TST software and saved in .shp format, in this format point cloud is readable by ArcGIS Figure 1. 


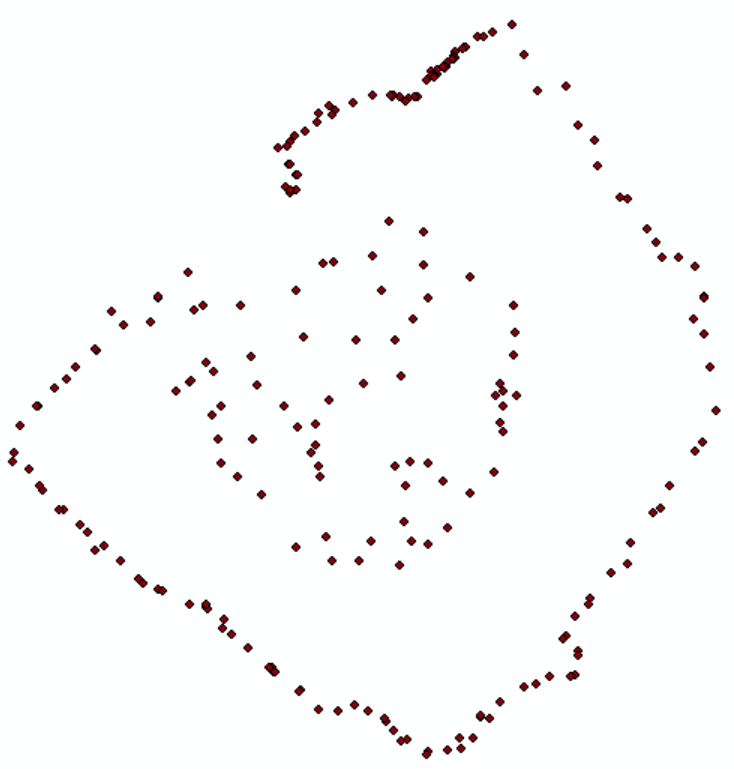

Figure 1. Point Cloud from TST data top view

In ArcGIS the first tool we used was "Create TIN" this tool is used to convert the point cloud into a representation of continuous surfaces derived from a spatial data structure generated from the triangulation process from which can be calculate the volume.

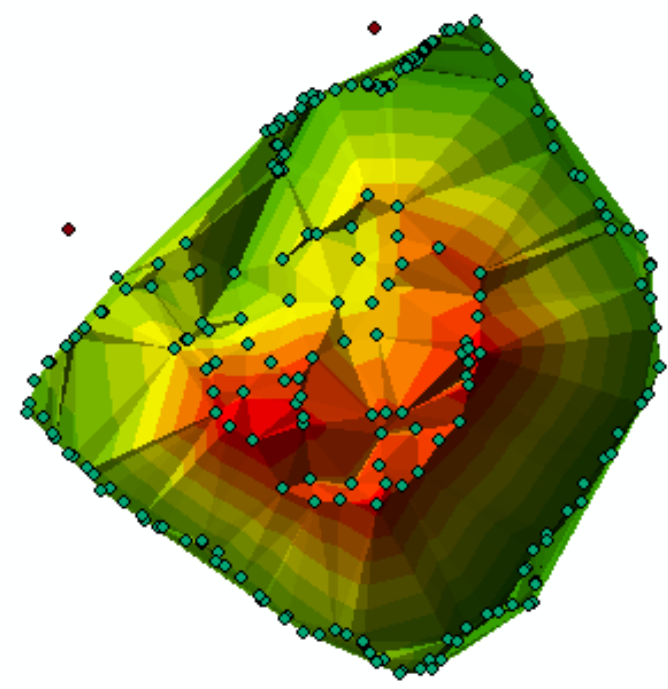

Figure 2. TIN Surface from TST data top view

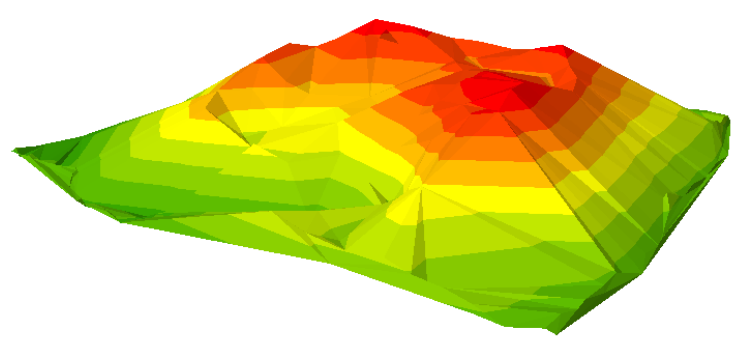

Figure 3. TIN Surface from TST data 3D view
Later "Surface Volume" tool is used, which as its name indicates calculates the volume of a TIN surface and finally we obtain the results in a table.

\subsubsection{Volume Estimation with UAV Data:}

To obtain the values of the stockpile volume, we adjust the image first with the GCP, these points was the same georeferenced points (with GNSS) around the stockpile that we use to set up the TST, after that, we use Pix4D software to estimate the volume, following this steps:

1. Draw a stockpile object

2. Change the manual tie points of the stockpile base to 3D GCPs

3. Change the altitude of the 3D GCPs to the desired altitude of the volume base.

4. Open the rayCloud and select the stockpile object to get the new volume calculation.

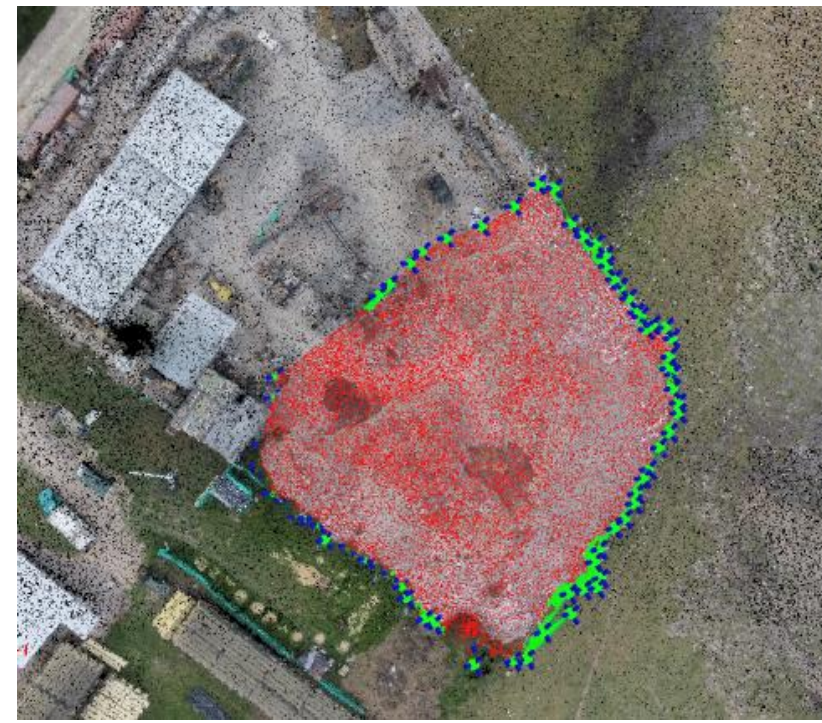

Figure 4. UAV Point cloud with stockpile drawing top view

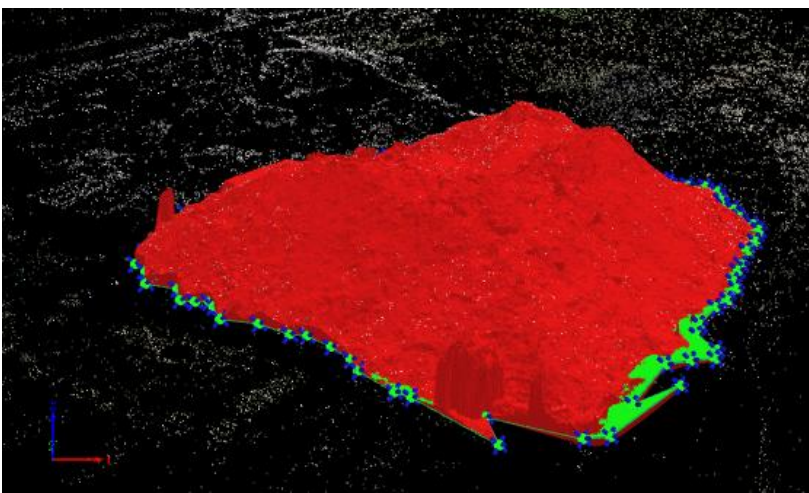

Figure 5. UAV Point cloud with Stockpile 3D view

After these process the software compute the volume automatically with the next process, according to Pix4D web page:

When creating a stockpile object, the user draws the base surface of the stockpile. This base surface is computed by applying a constrained Delaunay triangulation on its vertices, after that the software projects a grid with GSD spacing on the 
base and finally the software compute the volume with this formula

$$
V_{i}=L_{i} * W_{i}^{*} H_{i}
$$

Where: $L_{i}=$ the length of the cell.

$\mathrm{W}_{i}=$ the width of the cell.

$H_{i}=$ the height of the cell.

The Lenght (Li) and Width (Wi) are equal to the project 's GSD.

$$
L_{i}=W_{i}=G S D
$$

$\mathrm{GSD}=$ Ground Sample Distance

$$
H_{i}=Z_{T i} \quad Z_{B i}
$$

Where: $Z_{T i}=$ the terrain altitude of each cell at the center of the cell.

$Z_{B i}=$ the base altitude of each cell at the center of the cell.

Therefore, the volume $V_{i}$ of cell i is given by:

$$
V_{i}=G S D * G S D *\left(Z_{B i} \quad Z_{B i}\right)
$$

\section{RESULTS}

\subsection{Comparison of Stockpile Volumes}

Table 4 show the results of the stockpile volume by data obtained from TST and UAV, In addition, the table shows an actual information row, these data were collected from engineers recycling plant were the stockpile was, even though this information is approximate, for this case is assumed as the real volume.

\begin{tabular}{|l|ccccc|}
\hline & $\begin{array}{c}\text { Volume } \\
\mathrm{m}^{3}\end{array}$ & $\begin{array}{c}\text { Error } \\
(+/-) \\
\mathrm{m}^{3}\end{array}$ & $\begin{array}{c}\text { Difference } \\
\text { Volume } \\
\mathrm{m}^{3}\end{array}$ & Percentage & $\begin{array}{c}\text { Percentage } \\
\text { Difference }\end{array}$ \\
\hline Actual & 11500.00 & $\mathrm{n} / \mathrm{a}$ & - & - & - \\
TST & 11831.20 & $\mathrm{n} / \mathrm{a}$ & 331.20 & $102,88 \%$ & $2.88 \%$ \\
UAV & 11423.58 & 81.28 & -76.42 & $99,34 \%$ & $-0.67 \%$ \\
\hline
\end{tabular}

Table 4.Comparison stockpile volume results with actual volume

Based on the information provided in Table 4, there was a $2.88 \%$ difference between the volume calculated with the TST data and the actual volume, and $-0.67 \%$ difference between the volume calculated with the UAV data and the actual volume, a positive value indicates that the estimated volumen is higher than the actual volume and vice versa.

The percentage difference shows that the volume obtained with UAV data is more accurate than the volume obtained with TST data.

Additionally, if we consider the error obtained for the volume calculated with UAV data $\left(81.28 \mathrm{~m}^{3}\right)$, we have that the actual volume is in the range of the error, this can be seen easily in the
Figure 6, where the bar graph of measured volume with UAV data has the error bar

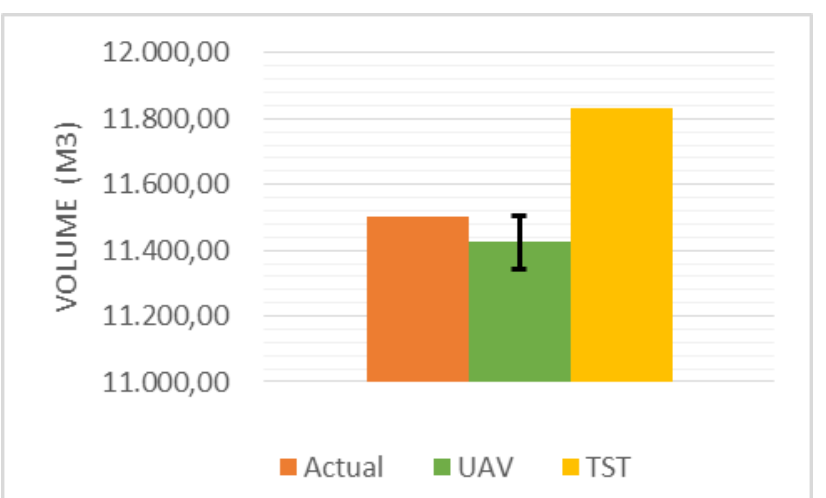

Figure 6. Comparison stockpile volume results with actual volume

\subsection{Time spent for data acquisition}

The information in Table 5 shows the time comparison between both methods, the first row shows the time taken for setup the equipment and the second row the time taken for obtain data.

\begin{tabular}{|l|cc|}
\hline Time taken for & TST & UAV \\
\hline Setup equipment & 5 minutes & 5 minutes \\
Obtain data & 3 hours & 30 minutes \\
\hline
\end{tabular}

Table 5. Time comparison between both methods

The table shows a clear difference between the two methods of data collection, the UAV is about 6 times faster than the TST, in addition, the risks of obtaining the data with the UAV are much lower, this because people are not exposed to unstable locations.

\section{CONCLUSION}

In this study, the traditional method with TST to estimate volumes of stockpile were compared with UAVs, data from the same site were taken and the post processing was done in ArcGIS with a TIN model from the point cloud data obtained with TST and in Pix4D from data obtained by the UAV

The results were compared with the actual volume of material, which was obtained from one of the engineers of the site where the data collection was performed.

After comparing the results it was found that there was a 2,88\% difference between the volume calculated with the TST data and the actual volume, and $-0,67 \%$ difference between the volume calculated with the UAV data and the actual volume, concluding that the estimated volume with UAV data is more accurate.

Additionally, we compare the time taken to get the data for the both methods, in this comparison, it was concluded that the UAV is about 6 times faster than the TST.

\section{REFERENCES}

Siebert, S., Teizer, J., 2014. Mobile 3D mapping for surveying earthwork projects using an Unmanned Aerial Vehicle (UAV) system. Automation in Construction, 41, pp. 1-14. 
Kavanagh, B.F., Glenn Bird, S.J., 1996. Surveying principles and applications (4 Ed.). Prentice Hall. pp. 257-264. ISBN 013-438300-1.

Eisenbeiß, H., 2009. UAV Photogrammetry, Dissertation Institute of Geodesy and Photogrammetry, ETH Zurich, Switzerland.

Ouédraogo, M.M., Degré, A., Debouche, C., Lisein, J., 2014. The evaluation of unmanned aerial system-based photogrammetry and terrestrial laser scanning to generate DEMs of agricultural watersheds. Geomorphology, 214, pp. 339-355.

Remondino, F., Barazzetti, L., Nex, F., Scaioni, M., Sarazzi, D., 2011, UAV photogrammetry for mapping and 3Dmodelingcurrent status and future perspectives, in: H. Eisenbeiss, M. Kunz, H. Ingensand (Eds.), Proceedings of the International Conference on Unmanned Aerial Vehicle in Geomatics (UAV-g) 2011, Zurich, Switzerland.

Zongjian, L.I.N., 2008, UAV for mapping-low altitude photogrammetric survey, International Archives of Photogrammetry and Remote Sensing, Beijing, China.

Gruen, A., 2012. Development and status of image matching in photogrammetry, Photogramm. Rec. 27, 36-57.

Leica Geosystems, website http://www.leicageosystems.com/en/Leica-FlexLine-TS02plus_99086.htm (accessed, June 20, 2015)

DJI, website http://www.dji.com/product/phantom-2-visionplus/spec (accessed, June 20, 2015)

Yakar and Yilmaz, 2008, Yakar,M and Yilmaz, H.M. Using In Volume Computing of Digital Close Range Photogrammetry, The International Archieves of the Photogrammetry, Remote Sensing and Spatial Information Sciences, Vol. XXXVII, Part B3b.

Hamzah, H.B., Said, S.M., 2011. Measuring volume of stockpile using imaging station. Geoinformation Science Journal, Vol. 11, No. 1, pp. 15-32

Pix4D, website https://support.pix4d.com (accessed, April 15, 2015) 